\title{
ANALISIS PEMASANGAN FILTER PASIF UNTUK MENGURANGI HARMONISA PADA TRANSFORMATOR RECTIFIER DI PT. INDAH KIAT PULP AND PAPER PERAWANG
}

\author{
Rido Rahmadani ${ }^{1}$, Atmam ${ }^{2}$, Elvira Zondra ${ }^{3}$ \\ 1,2,3 Program Studi Teknik Elektro, Fakultas Teknik, Universitas Lancang Kuning \\ Jl. Yos Sudarso km. 8 Rumbai, Pekanbaru, Telp. (0761) 52324 \\ Email: ridho.ramadhan007@gmail.com, atmam@unilak.ac.id, elviraz@unilak.ac.id
}

\begin{abstract}
ABSTRAK
Proses klor-alkali merupakan proses elektrolisis yang berperan penting dalam industri kimia seperti industri pembuatan bubur kertas (pulp industry). Proses elektrolisis ini membutuhkan rangkaian arus searah (Dirrect Current) dengan arus yang besar dan tegangan yang rendah. Dalam proses elektrolisis ini digunakan rectifier 12 pulsa terkontrol tiga phasa yang terhubung dengan multi winding transformator yang akan menimbulkan distorsi harmonik pada sisi sumber transformator dan menurunkan kualitas daya pada sistem. Untuk mengatasi masalah harmonik yang terjadi pada sistem, dilakukan analisis pemasangan peralatan berupa filter pasif jenis single tuned. Pemasangan filter pasif ini dapat mengurangi distorsi harmonik arus dan tegangan serta meningkatkan faktor daya $(\cos \varphi)$. Dari hasil simulasi harmonic analysis menggunakan software ETAP, setelah dilakukan pemasangan filter harmonik orde ke-11,13 dan 23 maka nilai harmonik arus $\left(\mathrm{THD}_{\mathrm{I}}\right)$ dan harmonik tegangan $\left(\mathrm{THD}_{\mathrm{v}}\right)$ terjadi penurunan yaitu sebelum pemasangan filter nilai $\mathrm{THD}_{\mathrm{I}}$ adalah $6,5 \%$, setelah pemasangan filter nilai $\mathrm{THD}_{\mathrm{I}}$ menjadi $0,98 \%$, terjadi penurunan $\mathrm{THD}_{\mathrm{I}}$ sebesar $5,52 \%$ dan nilai harmonik tegangan (THDv) sebelum pemasangan filter adalah 1,48\%, setelah pemasangan filter nilai $\mathrm{THD}_{\mathrm{v}}$ menjadi $0,26 \%$, terjadi penurunan $\mathrm{THD}_{\mathrm{v}}$ sebesar $1,22 \%$. Dari hasil simulasi aliran daya (load flow analysis), setelah dilakukan pemasangan filter terjadi peningkatan nilai faktor daya $(\cos \varphi)$ yaitu sebelum pemasangan filter nilai faktor daya $(\cos \varphi)$ adalah 0,8 setelah setelah pemasangan filter nilai faktor daya $(\cos \varphi)$ menjadi 0,96 terjadi peningkatan faktor daya sebesar $16 \%$.
\end{abstract}

Kata Kunci: filter harmonik, single tuned filter, faktor daya, transformator rectifier

\begin{abstract}
The chlor-alkali process is an electrolysis process which plays an important role in the chemical industry such as the pulp industry. The process produces a product in the form of $\mathrm{H}_{2}$ gas, $\mathrm{CL}_{2}$ gas and $\mathrm{NaOH}$ (where the source of chloride ion used is $\mathrm{NaCl}$ ). This electrolysis process requires a dirrect current with a large current and a low voltage. In this electrolysis process a three phase controlled 12 pulse rectifiers are used which a connected with multi-winding transformers. In the rectifiers process there will be harmonic distortion on the source side of the transformer which can reduce the power quality of the system. To overcome the harmonic problems that occur in the system, an installation analysis of the equipment in the form of a passive single tuned filter is aimed at reducing harmonic distortion of current and voltage and increasing the power factor $(\cos \varphi)$. From the result of harmonic analysis using ETAP software, after the installation of harmonic filters orde 11, 13 and 23 , the harmonic current value $\left(\mathrm{THD}_{\mathrm{I}}\right)$ and harmonic voltage $(\mathrm{THD})$ has decreased, namely, before the filter installation, $\mathrm{THD}_{\mathrm{I}}$ value is $6,5 \%$ whereas after installation of filters, $\mathrm{THD}_{\mathrm{I}}$ value becomes $0,98 \%$, thus there is a $\mathrm{THD}_{\mathrm{I}}$ decrease of $5,52 \%$. Furthermore, for the voltage harmonic value $\left(\mathrm{THD}_{\mathrm{v}}\right)$ before filter installation is $1,48 \%$ while after filtering, $\mathrm{THD}$ value becomes $0,26 \%$, thus there is a $\mathrm{THD}$ decrease of $1,22 \%$. From the results of the simulation of the flow of power (load flow analysis), after installation of filters there is an increase in the value of the power factor ( $\cos \varphi)$. Namely, before the filter installation, the value of power factor $(\cos \varphi)$ is 0,8 while after the filter installation the value of the power factor $(\cos \varphi)$ to 0,96 , thus an increase in the power factor $(\cos \varphi)$ of $16 \%$.
\end{abstract}

Keywords : harmonic filter, single tuned filter, power factor, transformer rectifier

\section{PENDAHULUAN}

Elektrolisis pada industri kimia adalah peristiwa penguraian elektrolit oleh arus listrik (proses yang merubah energi listrik menjadi energi kimia) menggunakan peralatan elektronika daya skala besar seperti rectifier 12 pulsa untuk menghasilkan arus searah yang besar. Dimana dalam 
proses penyearah tersebut digunakan komponen aktif thyristor yang akan menimbulkan distorsi harmonik pada sisi sumber transformator yang dapat menurunkan kualitas daya pada sistem.

Distorsi harmonik terutama harmonik arus merupakan salah satu permasalahan kualitas daya listrik yang cukup memiliki pengaruh besar terhadap kinerja sistem tenaga listrik di PT. Indah Kiat Pulp and Paper Perawang khususnya pada chemical plant. Permasalahan ini selain dapat merusak dan memperpendek umur peralatan juga menyebabkan terjadinya pemborosan energi seperti daya, penurunan kualitas faktor daya $(\cos \varphi)$, tegangan dan arus yang menyimpang dari kondisi idealnya. Chemical Plant unit 10 (CM-10) di PT. IKPP Perawang merupakan salah satu lokasi untuk mengolah larutan natrium klorida $(\mathrm{NaCl})$ menjadi natrium hidroksida $(\mathrm{NaOH})$ melalui proses elektrolisis dengan menggunakan transformator yang terhubung pada rectifier 12 pulsa.

\section{METODE PENELITIAN}

Berikut merupakan tahapan atau langkahlangkah penelitian dalam bentuk diagram alir (flowchart) yang akan dilakukan dalam mengamati dan merancang filter harmonik yang akan dipasang pada jaringan sistem kelistrikan transformator rectifier di unit CM-10 PT. Indah Kiat Perawang seperti pada Gambar 1 berikut :

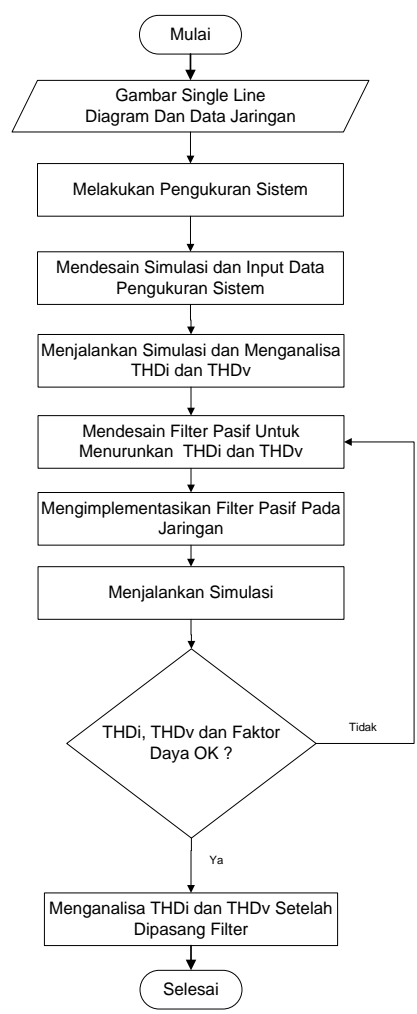

Gambar 1. Flowchart penelitian

\section{Sistem Kelistrikan Chemical Plant Unit 10 (CM- 10) Di PT.IKPP Perawang}

Sistem kelistrikan pada unit CM-10 di PT. IKPP Perawang disuplai oleh steam turbine generator dari unit Power Generating 2 (PG-2) yang sudah terhubung interkoneksi seperti pada gambar berikut :

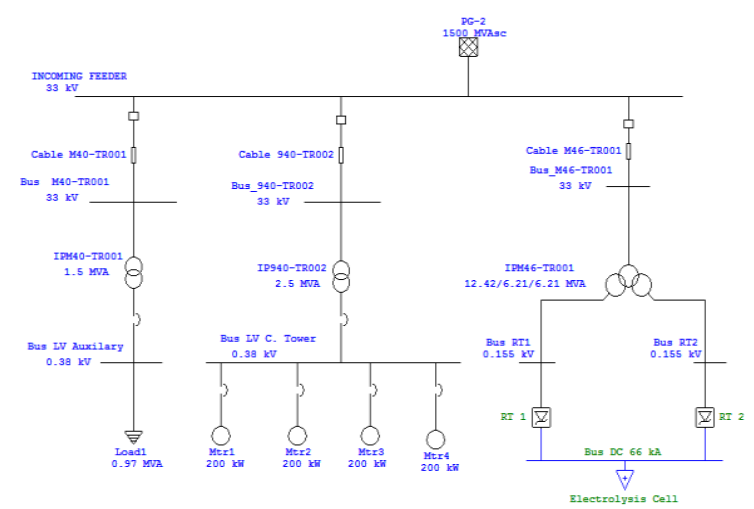

Gambar 2. Single line diagram pada sistem kelistrikan unit CM-10 PT. IKPP Perawang

\section{Transformator Rectifier}

Transformator rectifier digunakan dalam aplikasi di mana tegangan skunder divariasikan dalam rentang yang luas pada nilai arus yang konstan. Sangat sulit dan tidak ekonomis untuk memasang tap changer pada gulungan skunder karena jumlah lilitannya yang sangat rendah dan nilai arus yang sangat tinggi. Tap changer hanya bisa dipasang pada lilitan primer atau dengan menggunakan transformator dengan pengaturan terpisah (autotransformer) [1].

Transformator rectifier mengalami dampak harmonik akibat gelombang arus yang nonsinusoidal. Oleh karena itu, terkadang jumlah pulsa ditentukan berdasarkan pertimbangan yang diakibatkan oleh harmonik, sehingga untuk transformator penyearah dibutuhkan perhitungan rugi-rugi yang lebih rumit jika dibandingkan dengan transformator konvensional [2].

\section{Harmonik}

Harmonik atau yang biasa disebut harmonisa merupakan komponen sinusoidal dari sebuah gelombang periodik yang memiliki frekuensi kelipatan bulat dari fundamental frekuensi gelombang periodik tersebut [3]. Kemunculan harmonik merupakan suatu fenomena yang timbul akibat pengoperasian beban listrik nonlinear, yang merupakan sumber terbentuknya gelombang frekuensi tinggi (kelipatan dari frekuensi fundamental), distorsi harmonik dapat menimbulkan efek berbeda-beda yang terhubung dengan jaringan listrik terutama karekteristik beban listrik itu sendiri. Bentuk gelombang dari distorsi harmonik seperti pada Gambar 3 berikut : 


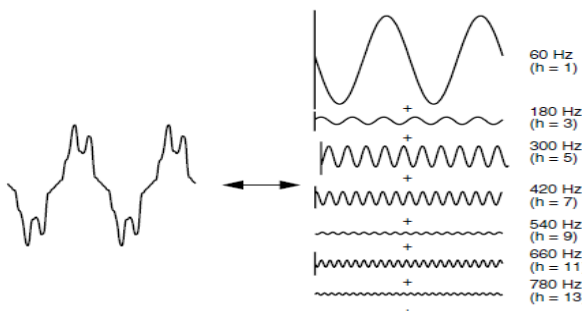

Gambar 3. Gelombang distorsi harmonik [4]

\section{Total Harmonic Distortion (THD)}

Total Harmonic Distortion (THD) digunakan untuk mendefinisikan efek harmonik pada tegangan sistem tenaga seperti sistem tegangan rendah, tegangan menengah, dan tegangan tinggi yang dinyatakan sebagai persen dari fundamental yang dapat dinyatakan dengan persamaan (1) berikut [5]:

$T H D_{V}=\frac{\sqrt{\sum_{h=2}^{\infty} \cdot V_{h}{ }^{2}}}{V_{1}} \times 100 \%$

Nilai THD untuk gelombang arus dinyatakan dengan persamaan (2) berikut [5] :

$T H D_{I}=\frac{\sqrt{\sum_{h=2}^{\infty} \cdot I_{h}{ }^{2}}}{I_{1}} \times 100 \%$

Keterangan :

$\mathrm{THD}_{\mathrm{V}}=$ Total Harmonic Distortion tegangan $(\%)$

$\mathrm{V}_{1}=$ Tegangan fundamental $(\mathrm{V})$

$\mathrm{V}_{\mathrm{h}} \quad=$ Tegangan harmonik ke-h $(\mathrm{V})$

$\mathrm{THD}_{\mathrm{I}}=$ Total Harmonic Distortion arus $(\%)$

$\mathrm{I}_{1} \quad=$ Arus fundamental (A)

$\mathrm{I}_{\mathrm{h}} \quad=$ Arus harmonik ke-h (A)

$\mathrm{h}=$ Bilangan orde harmonik

\section{Beban Nonlinear}

Harmonik akan disebabkan dengan adanya arus beban nonlinear yang impedansinya tidak konstan dalam setiap periode, beban nonlinear adalah beban di mana bentuk gelombang arus tidak sama dengan bentuk gelombang tegangan masukan. Sehingga nanti beban-beban nonlinear tidak mematuhi dan mengikuti hukum ohm yang menetapkan arus berbanding lurus dengan tegangan yang di hasilkan [5].

\section{Standar Harmonik IEEE 519-1992}

Harmonik juga memiliki batasan yang akan ditentukan dengan perbandingan arus hubung singkat pada PCC (Point of Common Coupling), dan arus beban $\left(\mathrm{I}_{\mathrm{L}}\right)$ biasa disebut arus beban fundamental. Batasan standar harmonik arus dan tegangan yang digunakan adalah standar IEEE 5191992 sebagai parameter batasan yang dapat dilihat pada Tabel 1 dan 2 berikut [3]:
Tabel 1. Batasan distorsi tegangan

\begin{tabular}{lcc}
\hline Bus Voltage at PCC & $\begin{array}{c}\text { Individual } \\
\text { Voltage } \\
\text { Distortion } \\
(\%)\end{array}$ & $\begin{array}{c}\text { Total } \\
\text { Voltage } \\
\text { Distortion } \\
\text { THD }(\%)\end{array}$ \\
\hline $69 \mathrm{kV}$ and Below & 3.0 & 5.0 \\
$69.001 \mathrm{kV}$ through $161 \mathrm{kV}$ & 1.5 & 2.5 \\
$161.001 \mathrm{kV}$ and above & 1.0 & 1.5 \\
\hline
\end{tabular}

(Sumber: Standar IEEE 519-1992).

Tabel 2. Batasan distorsi arus

Maximum Harmonic Current Distortion in \% of $I_{L}$

Individual Harmonic order (Odd Harmonics)

\begin{tabular}{ccccccc}
\hline $\mathrm{ISC}_{\mathrm{SC}} / \mathrm{I}_{\mathrm{L}}$ & $<11$ & $\begin{array}{c}11- \\
16\end{array}$ & $\begin{array}{c}17- \\
23\end{array}$ & $\begin{array}{c}24- \\
34\end{array}$ & $>34$ & $\%$ THD \\
\hline$<20$ & 4.0 & 2.0 & 1.5 & 0.6 & 0.3 & 5.0 \\
$20<50$ & 7.0 & 3.5 & 2.5 & 1.0 & 0.5 & 8.0 \\
$50<100$ & 10.0 & 4.5 & 4.0 & 1.5 & 0.7 & 12.0 \\
$100<1000$ & 12.0 & 5.5 & 5.0 & 2.0 & 1.0 & 15.0 \\
$>1000$ & 15.0 & 7.0 & 6.0 & 2.5 & 1.4 & 20.0 \\
\hline
\end{tabular}

Tujuan dari batasan distorsi harmonik adalah untuk membatasi frekuensi tegangan individu harmonik maksimum menjadi 3\% dari fundamental dan $\mathrm{THD}_{\mathrm{v}}$ hingga 5\% untuk sistem tanpa resonansi paralel utama. Menurut IEEE Standard 519-1992, untuk mengetahui standar batas maksimum $\mathrm{THD}_{\mathrm{I}}$ pada jaringan kelistrikan, maka harus diketahui terlebih dahulu rasio hubung singkat $\left(\mathrm{SC}_{\text {ratio }}\right)$ agar dapat menghitung batas maksimum $\mathrm{THD}_{\mathrm{I}}$. Nilai hubung singkat $\left(\mathrm{SC}_{\text {ratio }}\right)$ akan dapat ditentukan dengan dengan persamaan berikut [4]:

$$
\begin{aligned}
& S C_{\text {ratio }}=\frac{I_{S C}}{I_{L}} \\
& I_{S C}=\frac{100 \times M V A}{\sqrt{3} \times k V}
\end{aligned}
$$

$I_{L}=\frac{k W}{P f \times \sqrt{3} \times k V}$

Keterangan :

$\mathrm{SC}_{\text {ratio }}=$ Rasio hubung singkat

$\mathrm{I}_{\mathrm{SC}} \quad=$ Arus hubung singkat maksimum pada PCC (A)

$\mathrm{I}_{\mathrm{L}} \quad=$ Arus beban maksimum $(\mathrm{A})$

$\mathrm{kW}=$ Total daya aktif (Watt)

$\mathrm{Pf} \quad=$ Faktor daya sistem

\section{Pengaruh yang Ditimbulkan Oleh Harmonik}

Arus harmonik yang dihasilkan oleh beban nonlinear disuntikkan kembali ke dalam sumber sistem. Arus ini dapat berinteraksi secara negatif dengan berbagai peralatan sistem tenaga listrik, terutama kapasitor, transformator, dan motor, sehingga menyebabkan rugi-rugi tambahan seperti 
peralatan listrik menjadi terlalu panas, dan kelebihan beban.

\section{Filter Hamonik Pasif}

Filter pasif merupakan rangkaian yang tersusun dari komponen pasif seperti induktor, kapasitor, dan resistor. Filter pasif ini mempunyai beberapa bentuk berdasarkan susunan rangkaian komponen penyusun seperti pada Gambar 4. Secara umum filter pasif dapat dibedakan dalam tiga jenis :

a. Filter dengan penalaan tunggal (Single Tuned Shunt Filter).

b. Filter dengan penalaan ganda (Double Tuned Filter).

c. High Pass Damp Filter Type.

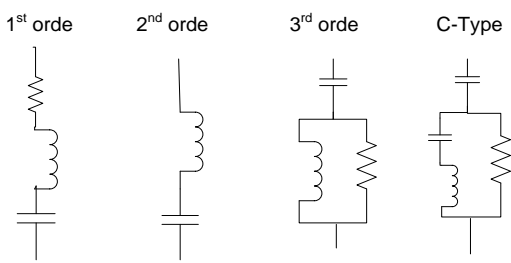

Gambar 4. Jenis filter pasif berdasarkan susunan rangkaian komponen [5]

Dengan penambahan filter harmonik pada suatu sistem tenaga listrik yang mengandung sumber harmonik, maka penyebaran arus harmonik keseluruh sistem dapat ditekan sekecil mungkin. Selain itu, filter harmonik pada frekuensi fundamental dapat mengkompensasi daya reaktif yang digunakan untuk memperbaiki faktor daya sistem. Filter pasif menyediakan impedansi yang sangat rendah pada frekuensi tuning, di mana semua arus frekuensi tertentu akan dialihkan. Semua arus harmonik yang frekuensinya bertepatan dengan frekuensi yang diatur pada filter akan menemukan jalur impedansi rendah melalui filter. Frekuensi resonansi dari filter pasif ini dapat dihitung dengan persamaan (6) berikut [5] :

$f_{0}=\frac{1}{2 \times \pi \times \sqrt{(L \times C)}}$

Keterangan :

$\mathrm{f}_{0} \quad=$ Frekuensi resonansi $(\mathrm{Hz})$

$\mathrm{L} \quad=$ Induktansi filter $(\mathrm{H})$

$\mathrm{C}=$ Kapasitansi filter $(\mathrm{F})$

Faktor kualitas $\left(\mathrm{Q}_{\mathrm{f}}\right)$ dari filter adalah rasio antara reaktansi induktif atau kapasitif terhadap resonansi dan resistansi. Nilai-nilai khas $\mathrm{Q}_{\mathrm{f}}$ berfluktuasi antara 15 sampai 80 untuk filter yang digunakan dalam industri. Persamaan (7) berikut digunakan untuk menghitung faktor kualitas [5] :

$Q_{f}=\frac{X_{L}}{R}=\frac{X_{C}}{R}$
Keterangan :

$\mathrm{Q}_{\mathrm{f}}=$ Faktor kualitas

$\mathrm{X}_{\mathrm{L}}=$ Reaktansi induktif pada reaktor filter $(\Omega)$

$\mathrm{X}_{\mathrm{C}}=$ Reaktansi kapasitif pada kapasitor filter $(\Omega)$

$\mathrm{R}=$ Resistansi filter $(\Omega)$

\section{Perhitungan Spesifikasi Single Tuned Filter}

Langkah-langkah untuk mengatur filter harmonik menggunakan hubungan dasar dapat diuraikan sebagai berikut [5]:

a. Hitung nilai kapasitansi yang dibutuhkan untuk meningkatkan faktor daya. Kompensasi faktor daya umumnya digunakan untuk meningkatkan faktor daya menjadi 0,95 atau lebih.

b. Pilih reaktor untuk mengatur kapasitor seri ke frekuensi harmonik yang diinginkan.

c. Hitung tegangan puncak pada terminal kapasitor dan arus reaktor rms.

d. Pilih standar komponen untuk filter dan verifikasi kinerja filter untuk memastikan bahwa komponen kapasitor akan beroperasi dalam batas yang direkomendasikan IEEE-18.

\section{HASIL DAN PEMBAHASAN}

Titik pengukuran harmonik dalam penelitian ini adalah pada sisi tegangan input $33 \mathrm{kV}$ transformator rectifier melalui peralatan Potensial Transformer (PT) dan Current Transformer (CT). Spesifikasi main bus sistem, transformator dan rectifier dengan nomor function location IPM46TR001 seperti pada Tabel 3,4, dan 5 berikut :

Tabel 3. Spesifikasi data sistem Main Bus $33 \mathrm{kV}$

\begin{tabular}{lc}
\hline Spesifikasi & Kapasitas \\
\hline Frekuensi (Hz) & 50 \\
Jumlah Phasa & 3 \\
Tegangan (V) & 33.000 \\
Arus (A) & 1.200 \\
Daya Short Circuit Maksimum (MVA) & 1.500 \\
\hline
\end{tabular}

(Sumber : PT. IKPP Perawang).

Tabel 4. Spesifikasi transformator IPM46-TR001

\begin{tabular}{|c|c|c|}
\hline Spesifikasi & $\begin{array}{c}\text { Tegangan } \\
\text { AC }\end{array}$ & $\begin{array}{c}\text { Tegangan } \\
\text { DC }\end{array}$ \\
\hline Kapasitas Daya (KVA) & 12.420 & $\begin{array}{c}2 \times 2 \times 2 \times \\
2272\end{array}$ \\
\hline Jumlah Phasa & 3 & $2 \times 2 \times 2 \times 3$ \\
\hline Tegangan (V) & 33.000 & 159 \\
\hline Arus (A) & 217 & 4.763 \\
\hline Frekuensi (Hz) & \multicolumn{2}{|c|}{50} \\
\hline Impedansi Tegangan (\%) & \multicolumn{2}{|c|}{ 6,46 (12.420 kVA Base) } \\
\hline Kapasitas Isolasi Minyak (L) & \multicolumn{2}{|c|}{17.800} \\
\hline Berat Total (Kg) & \multicolumn{2}{|c|}{54.000} \\
\hline Jenis Pendingin & \multicolumn{2}{|c|}{ OFWF } \\
\hline Nomor Seri & \multicolumn{2}{|c|}{ A1U69115T1 } \\
\hline Tahun Pembuatan & \multicolumn{2}{|c|}{1996} \\
\hline Merk & \multicolumn{2}{|c|}{ Fuji Electric } \\
\hline
\end{tabular}

(Sumber : PT. IKPP Perawang)

Tabel 5. Spesifikasi rectifier 


\begin{tabular}{lc}
\hline Spesifikasi & Kapasitas \\
\hline Kapasitas Daya (kW) & 10.362 \\
Tegangan (Vdc) & 157 \\
Arus (Adc) & 66.000 \\
Frekuensi (Hz) & 50 \\
Tegangan Uji Frekuensi Rendah $(\mathrm{kV})$ & 2 \\
Faktor pengontrolan $(\%)$ & 8,65 \\
Berat Total (Kg) & 10.000 \\
Jenis Pendingin & AFWF \\
Berat Peralatan Pendingin (Kg) & 1.900 \\
Kapasitas Air pendingin (L) & 440 \\
Merk & Fuji Electric \\
\hline
\end{tabular}

(Sumber: PT. IKPP Perawang)

\section{Data Hasil Pengukuran}

Data pengukuran THD arus, THD tegangan dan beban hasil pengukuran menggunakan alat ukur EMPATH 2000 seperti pada Tabel 6 berikut :

Tabel 6. Nilai pengukuran THD dan persentase beban

\begin{tabular}{lc}
\hline Frekuensi Sistem $(\mathrm{Hz})$ & 49,38 \\
THDi $(\%)$ & 6,155 \\
THDv (\%) & 2,433 \\
Beban (\%) & 75,1 \\
\hline
\end{tabular}

Nilai konsumsi energi listrik dan kualitas daya hasil pengukuran adalah seperti pada Tabel 7 berikut :

Tabel 7. Nilai pengukuran konsumsi energi dan kualitas

\begin{tabular}{lcccc}
\multicolumn{1}{c}{ daya } & \multicolumn{1}{c}{$\mathrm{R}$} & $\mathrm{S}$ & $\mathrm{T}$ & Total \\
\hline Phasa & 0,81 & 0,813 & 0,801 & 0,808 \\
\hline Faktor Daya (Cos $\varphi)$ & $2.585,6$ & $2.647,4$ & $2.549,7$ & $7.782,7$ \\
Daya Aktif (kW) & $1.873,2$ & $1.897,8$ & $1.907,4$ & $5.678,4$ \\
Daya Reaktif (kVAR) & $3.192,8$ & $3.257,3$ & $3.184,2$ & $9.634,4$ \\
Daya Semu (kVA) & 167,7 & 170,7 & 167,7 & 168,7 \\
RMS Arus (A) & 13,7 & 32.986 & 32.901 & 32.975 \\
RMS Tegangan (V) & 33.039 & & &
\end{tabular}

Bentuk gelombang dan spektrum arus dari hasil pengukuran sperti pada Gambar 5 dan 6 berikut :

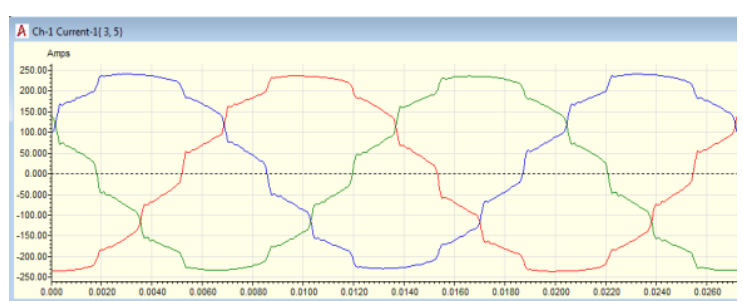

Gambar 5. Gelombang arus pada sisi input transformator rectifier

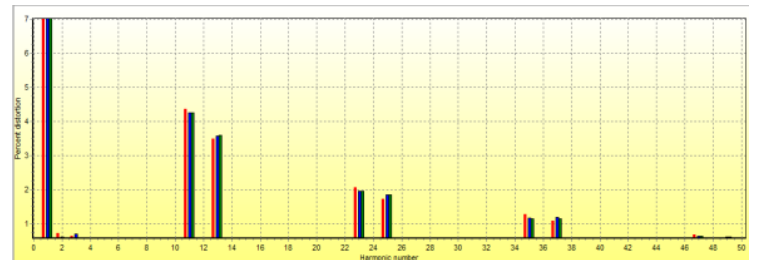

Gambar 6. Spektrum harmonik arus pada sisi input transformator rectifier

Bentuk gelombang dan spektrum tegangan dari hasil pengukuran seperti pada Gambar 7 dan 8 berikut :
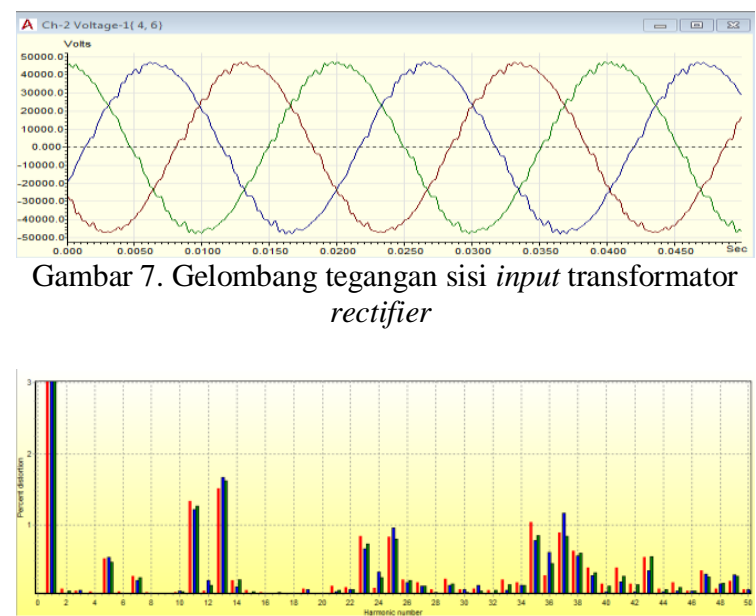

Gambar 8. Spektrum harmonik tegangan sisi input transformator rectifier

\section{Penilaian THD Arus Berdasarkan Standar IEEE 519-1992}

Perhitungan nilai arus hubung singkat $\left(\mathrm{I}_{\mathrm{sc}}\right)$ pada Point of Common Coupling (PCC) berdasarkan data spesifikasi pada Tabel 3, dan dengan menggunakan persamaan (4) maka nilai arus hubung singkat maksimum pada PCC adalah :

$I_{S C}=\frac{1000 \times M V A}{\sqrt{3} \times k V}=\frac{1000 \times 1500}{\sqrt{3} \times 33}=26.243,194 \mathrm{~A}$

Arus beban $\left(\mathrm{I}_{\mathrm{L}}\right)$ pada sisi sumber transformator rectifier pada kondisi beban rata-rata $75 \%$ adalah :

$I_{L}=\frac{k W}{P f \times \sqrt{3} \times k V}=\frac{7.782,7}{0,8 \times \sqrt{3} \times 33}=170 \mathrm{~A}$

Maka nilai rasio hubung singkat ( $\mathrm{SC}_{\text {ratio }}$ ) pada $\mathrm{PCC}$ dapat ditentukan dengan menggunakan persamaan (3) sehingga nilai $\mathrm{SC}_{\text {ratio }}$ adalah :

$S C_{\text {ratio }}=\frac{I_{S C}}{I_{L}}=\frac{26.243,194}{170}=154,37$

Berdasarkan standar IEEE 519-1992 pada Tabel 2, nilai rasio hubung singkat $\left(\mathrm{SC}_{\text {ratio }}\right)$ berada pada nilai ratio $100<1000$, maka nilai $\mathrm{THD}$ arus maksimum yang diperbolehkan adalah sebesar $15 \%$. Pemasangan filter pasif dilakukan untuk menghilangkan distorsi harmonik arus yang mulai terbentuk dan meningkatkan efisiensi kualitas daya $(\cos \varphi)$.

Analisa dan perhitungan filter harmonik pasif jenis single tuned yang akan dihitung yaitu pada orde harmonik arus yang nilainya dominan lebih tinggi yaitu orde $11,13,23$, dan 25 pada sisi sumber transformator rectifier IPM46-TR001.

Dari spesifikasi sistem diketahui bahwa tegangan kerja antar phasa $\left(\mathrm{V}_{\mathrm{L}-\mathrm{L}}\right)$ adalah sebesar : 


$$
V_{L-L}=33.000 \text { Volt }=33 \mathrm{kV}
$$

Sistem kelistrikan bekerja pada frekuensi $50 \mathrm{~Hz}$ maka besarnya nilai radian sudut $(\omega)$ adalah sebagai berikut :

$\omega=2 \times \pi \times f=2 \times 3,14 \times 50=314$

\section{Menentukan Kapasitor Filter Untuk Menentukan Daya Reaktif}

Persyaratan daya reaktif kapasitif untuk faktor daya dan kontrol tegangan umumnya menentukan ukuran efektifitas kVAR dari filter harmonik. Nilai kVAR filter harmonik yang efektif selalu kurang dari kVAR nameplate dari kapasitor filter harmonik. Nilai daya reaktif efektif $\left(\mathrm{Q}_{\mathrm{eff}}\right)$ tiga phasa dihitung dengan persamaan berikut [5] :

$$
\begin{aligned}
Q_{\text {eff_3Phasa }} & =P \times\left[\tan \left(\theta_{1}\right)-\tan \left(\theta_{2}\right)\right] \\
& =P \times\left[\tan \left(\cos ^{-1} \varphi_{\text {awal }}\right)-\tan \left(\cos ^{-1} \varphi_{\text {target }}\right)\right] \\
& =7.782,7 \times\left[\tan \left(\cos ^{-1} 0,8\right)-\tan \left(\cos ^{-1} 0,98\right)\right] \\
& =4,280 \mathrm{MVAR} \\
Q_{\text {eff_1Phasa }} & =\frac{Q_{\text {eff_3phasa }}}{3}=\frac{4.280,485}{3}=1.427 \text { MVAR }
\end{aligned}
$$

Keterangan :

$\mathrm{Q}_{\mathrm{eff}}=$ Daya reaktif yang efektif dari filter harmonik (VAR)

$\mathrm{P} \quad=$ Daya yang terbentuk oleh beban dan diterima oleh sistem (W)

$\varphi_{\text {awal }}=$ Nilai faktor daya sebelum dipasang filter

$\varphi_{\text {target }}=$ Nilai faktor daya yang akan dicapai

\section{Pemilihan Frekuensi Tuning Filter}

Filter biasanya akan diatur ke frekuensi terendah dari harmonik yang paling signifikan. Filter harmonik biasanya diatur ke frekuensi sekitar $3 \%$ hingga $15 \%$ di bawah frekuensi harmonik yang dipilih. Reaktansi efektif dari kapasitor filter untuk orde ke-11 dapat dihitung dengan persamaan berikut [5] :

$$
X_{C 1}=\frac{\left.V_{L-L}^{2}(k V)\right)}{Q_{\text {eff }}(M V A R)}=\frac{33^{2}}{1,427}=763,14 \Omega
$$

Maka nilai kapasitor untuk komponen filter (dalam Farad) adalah sebesar :

$$
C=\frac{1}{\omega \times X_{C 1}}=\frac{1}{314 \times 763,14}=4,173 \mu \mathrm{F}
$$

Keterangan :

$\mathrm{X}_{\mathrm{C} 1}=$ Reaktansi efektif kapasitor filter harmonik pada frekuensi dasar $(\Omega)$

$\mathrm{Q}_{\text {eff }}=$ Daya reaktif yang efektif dari filter harmonik (MVAR)

$\mathrm{V}_{\mathrm{L}-\mathrm{L}}=$ Tegangan nominal line to line pada sistem $(\mathrm{kV})$

Nilai reaktor seri pada frekuensi fundamental $\left(\mathrm{X}_{\mathrm{L} 1}\right)$ untuk induktor filter ored ke-11 dapat ditentukan dengan menggunakan persamaan berikut :

$X_{L 1}=\frac{X_{C 1}}{h^{2}}=\frac{763,14}{10,8^{2}}=6,543 \Omega$

Sehingga nilai induktor untuk komponen filter (dalam Henry) adalah sebesar :

$$
L=\frac{X_{L 1}}{\omega}=\frac{6,543}{314}=0,020837 \mathrm{H}=20,837 \mathrm{mH}
$$

Dengan penentuan nilai kualitas faktor $\left(Q_{f}\right)=60$, maka besarnya nilai resistansi (R) filter harmonik orde ke-11 adalah :

$$
R=\frac{X_{L 1}}{Q_{f}}=\frac{6,543}{60}=0,109 \Omega
$$

\section{Penentuan Parameter Operasi Kapasitor Filter}

Arus yang melalui kapasitor dihitung dalam tegangan phasa ke netral maksimum, maka besarnya nilai arus yang melalui kapasitor filter harmonik orde ke-11 pada frekuensi fundamental $\left(\mathrm{I}_{\mathrm{Cl}}\right)$ adalah :

$I_{C 1}=(1,05) \times \frac{V_{L-N}}{\left(X_{C 1}-X_{L 1}\right)}=(1,05) \times \frac{\left(\frac{33.000}{\sqrt{3}}\right)}{(763,14-6,543)}=26,44 \mathrm{~A}$

Jika kita asumsikan arus harmonik dari beban berbanding terbalik dengan arus fundamental dengan daya semu beban hasil pengukuran sebesar 9.634,4 kVA pada Tabel 8, maka nilai arus pada harmonik orde ke-11 ( $\left.\mathrm{I}_{\mathrm{C} 11}\right)$ adalah :

$I_{C 11}=\frac{1}{h} \times \frac{k V A_{\text {Load }}}{\sqrt{3} \times 33}=\frac{1}{10,8} \times \frac{9634,4}{57,157}=15,6 \mathrm{~A}$

Arus rms ( $\left.\mathrm{I}_{\mathrm{C}_{-} \text {rms }}\right)$ yang melalui kapasitor adalah penjumlahan dari semua arus rms yang akan mengalir melalui filter. Asumsinya di sini adalah bahwa hanya harmonik orde ke-11 yang difilter, maka nilai arus rms adalah :

$I_{C_{-} r m s}=\sqrt{\left(I_{C 1}^{2}+I_{C 11}^{2}\right)}=\sqrt{\left(26,44^{2}+15,6^{2}\right)}=30,69 \mathrm{~A}$ 
Nilai reaktansi kapasitor filter pada frekuensi harmonik orde ke-11 $\left(\mathrm{X}_{\mathrm{C} 11}\right)$ adalah :

$$
X_{C 11}=\frac{X_{C 1}}{h}=\frac{763,14}{10,8}=70,66 \Omega
$$

Nilai tegangan yang melaui kapasitor pada frekuensi fundamental $\left(\mathrm{V}_{\mathrm{Cl}}\right)$ adalah :

$$
V_{C 1}=X_{C 1} \times I_{C 1}=763,14 \times 26,44=20.177,42 \mathrm{~V}
$$

Nilai tegangan yang melaui kapasitor pada pada saat frekuensi harmonik orde ke-11 $\left(\mathrm{V}_{\mathrm{C} 11}\right)$ ditentukan berdasarkan dari spektrum harmonik arus $\left(\mathrm{I}_{\mathrm{Ch}}\right)$ khas dari beban nonliniear yang sesuai, maka besarnya nilai tegangan pada frekuensi harmonik orde ke-11 adalah :

$$
V_{C 11}=X_{C 11} \times I_{C 11}=70,66 \times 15,6=1.102,3 \mathrm{~V}
$$

Nilai tegangan rms ( $\left.\mathrm{V}_{\mathrm{C}_{-} \text {rms }}\right)$ yang melalui kapasitor filter tersebut adalah :

$$
\begin{aligned}
V_{C_{-} r m s} & =\sqrt{\left(V_{C 1}{ }^{2}+V_{C 11}^{2}\right)} \\
& =\sqrt{\left(20.177,42^{2}+1.102,3^{2}\right)}=20.207,5 \mathrm{~V}
\end{aligned}
$$

Nilai tegangan puncak $\left(\mathrm{V}_{\mathrm{C}_{\text {_peak }}}\right)$ yang melalui kapasitor adalah :

$$
\begin{aligned}
V_{C_{-} \text {Peak }} & =\sqrt{2} \times\left(V_{C 1}+V_{C 11}\right) \\
& =\sqrt{2} \times(20.177,42+1.102,3)=30.094,06 \mathrm{~V}
\end{aligned}
$$

\section{Menentukan Parameter Operasi Kapasitor Filter} Standar IEEE-18 merekomendasikan batasan untuk pengoperasian kapasitor shunt dalam sistem daya termasuk arus, daya, dan tegangan di seluruh unit kapasitor. kapasitor dirancang untuk dioperasikan pada atau di bawah tegangan pengenalnya untuk dapat beroperasi sesuai dengan ketentuan batasan pada Tabel 8 berikut :

Tabel 8. Batasan operasi maksimum kapasitor standar IEEE-18

\begin{tabular}{ll}
\hline Daya reaktif yang terbentuk (VAR) & $135 \%$ \\
Tegangan RMS & $110 \%$ \\
Tegangan yang terukur dan termasuk & $120 \%$ \\
tegangan harmonik & $135 \%$ \\
Arus RMS & \\
\hline
\end{tabular}

(Sumber : Rosa, 2006)

Jika tegangan line to netral $\left(\mathrm{V}_{\mathrm{L}-\mathrm{N}}\right)$ pada sistem 33.000 Volt adalah sebesar 19.052,55 Volt, maka perbandingan nilai per-unit $(\mathrm{Pu})$ tegangan $\mathrm{rms}$ $\left(\mathrm{V}_{\mathrm{C} \_ \text {rms }}\right)$ dan tegangan puncak $\left(\mathrm{V}_{\mathrm{C} \_ \text {_peak }}\right)$ yang mengalir pada kapasitor adalah sebagai berikut :

Perbandingan nilai tegangan rms kapasitor ( $\left.\mathrm{V}_{\mathrm{C} \_ \text {rms }}\right)$ dalam $\mathrm{Pu}$ :

$\frac{V_{C_{-} \text {rms }}}{V_{C_{-} \text {rated }}}=\frac{20.207,5}{19.052,55}=1,06 \mathrm{Pu}$

(Nilai masih dibawah standar IEEE-18 yaitu $<1,1$ $\mathrm{Pu}$ )

Perbandingan nilai tegangan puncak kapasitor ( $\left.\mathrm{V}_{\mathrm{C} \_ \text {peak }}\right)$ dalam $\mathrm{Pu}$ :

$\frac{V_{C_{-} \text {peak }}}{V_{C_{-} \text {peak_rated }}}=\frac{30.094,06}{\sqrt{2} \times 19.052,55}=1,116 \mathrm{Pu}$

(Nilai masih dibawah standar IEEE-18 yaitu $<1,2$ $\mathrm{Pu}$ )

Daya reaktif yang disediakan oleh kapasitor filter adalah :

$$
\frac{\left(V_{C_{-} r m s}\right) \times\left(I_{C_{-} r m s}\right)}{1000}=\frac{(20.207,5) \times(30,69)}{1000}=620,168 \mathrm{kVAR}
$$

Maka besarnya daya reaktif kapasitor tiga phasa adalah sebesar :

$\mathrm{kVAR}_{3_{-} \text {phasa }}=620,168 \times 3=1.860,504 \mathrm{kVAR}$

\section{Evaluasi Respon Frekuensi Filter}

Nilai frekuensi respon $\left(\mathrm{f}_{\text {Res }}\right)$ dari filter untuk harmonik orde ke-11 adalah :

$$
f_{\text {res }}=\frac{1}{2 \times \pi \times \sqrt{\left(20,837 \times 10^{-3}\right) \times\left(4,173 \times 10^{-6}\right)}}=540,5 \mathrm{~Hz}
$$

\section{Tabulasi Hasil Perhitungan}

Dengan menggunakan perhitungan yang sama, maka nilai komponen kapasitor (C), induktor (L) , reaktansi induktor $\left(\mathrm{X}_{\mathrm{L}}\right)$, resistor $(\mathrm{R})$ serta karaktristik filter selanjutnya yang akan digunakan pada setiap orde harmonik (h) yaitu orde harmonik ke13,23 dan 25 adalah seperti pada Tabel 9 dan 10 berikut :

Tabel 9. Nilai komponen filter satu phasa

\begin{tabular}{cccccc}
\hline $\begin{array}{c}\text { Volt } \\
(\mathrm{kV})\end{array}$ & Orde & $\begin{array}{c}\mathrm{C} \\
(\mu \mathrm{F})\end{array}$ & $\begin{array}{c}\mathrm{L} \\
(\mathrm{mH})\end{array}$ & $\begin{array}{c}\mathrm{X}_{\mathrm{L}} \\
(\Omega)\end{array}$ & $\begin{array}{c}\mathrm{R} \\
(\Omega)\end{array}$ \\
\hline & 11 & 4,173 & 20,837 & 6,543 & 0,109 \\
33 & 13 & 4,173 & 14,833 & 4,657 & 0,077 \\
& 23 & 4,173 & 4,675 & 1,468 & 0,024 \\
& 25 & 4,173 & 3,949 & 1,24 & 0,0206 \\
\hline
\end{tabular}

Tabel 10. Karakteristik Filter 


\begin{tabular}{cccccccc}
\hline $\begin{array}{c}\text { Orde } \\
\begin{array}{c}\text { Harmo } \\
\text { nik }\end{array}\end{array}$ & $\begin{array}{c}\text { Arus } \\
\text { (A) }\end{array}$ & $\begin{array}{c}\text { Arus } \\
\text { RMS } \\
\text { (A) }\end{array}$ & $\begin{array}{c}\text { V } \\
\text { Kapasitor } \\
(\mathrm{kV})\end{array}$ & $\begin{array}{c}\text { Tegangan } \\
\text { Kapasitor } \\
(\mathrm{kV})\end{array}$ & $\begin{array}{c}\text { Daya Kapasitor } \\
\text { 1 Phasa }\end{array}$ & $\begin{array}{c}\text { Respon } \\
\text { (kVAR) }\end{array}$ & $\begin{array}{c}\text { Frekuensi } \\
(\mathrm{Hz})\end{array}$ \\
\hline 11 & 15,6 & 30,69 & 20,207 & 30,094 & 620,16 & 1.860 & 540,5 \\
13 & 13,169 & 29,47 & 20,143 & 29,575 & 593,6 & 1.780 & 641,02 \\
23 & 7,393 & 27,28 & 20,046 & 28,697 & 546,86 & 1.640 & $1.140,25$ \\
25 & 6,796 & 27,11 & 20,033 & 28,625 & 543,2 & 1.629 & $1.242,2$ \\
\hline
\end{tabular}

\section{Simulasi Sistem Kelistrikan CM-10 Menggunakan} Software ETAP

Simulasi sistem ini bertujuan untuk membandingkan seberapa besar selisih tingkat distorsi harmonik arus dan tegangan dari hasil pengukuran dengan hasil simulasi pada sistem serta mengetahui kondisi awal saat sebelum dan setelah dipasang filter single tuned pada sistem dengan menggunakan software ETAP versi 12.6. Data untuk parameter komponen mengacu pada nilai-nilai aktual berdasarkan pada nameplate.

\section{Simulasi Aliran Daya dan THD Sistem Sebelum Pemasangan Filter}

Berdasarkan data pengukuran pada Tabel 6 dan Tabel 7, maka hasil simulasi menggunakan software ETAP adalah seperti pada Gambar 9 berikut :

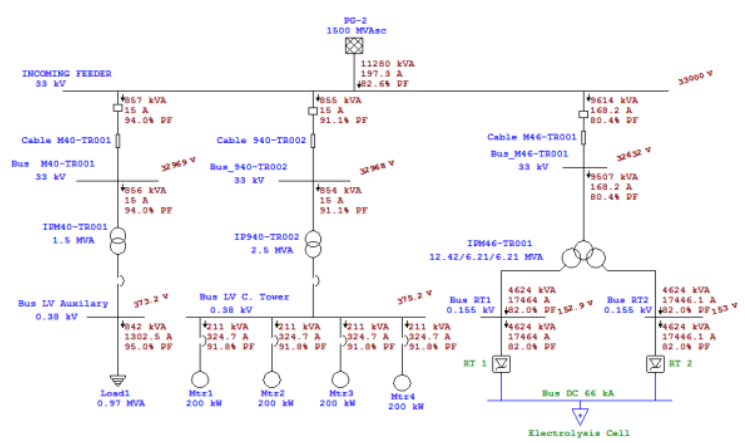

Gambar 9. Simulasi aliran daya sebelum pemasangan filter

Nilai THD arus dan tegangan pada sisi sumber transformator rectifier IPM46-TR001 dari hasil simulasi seperti pada Gambar 10 berikut :

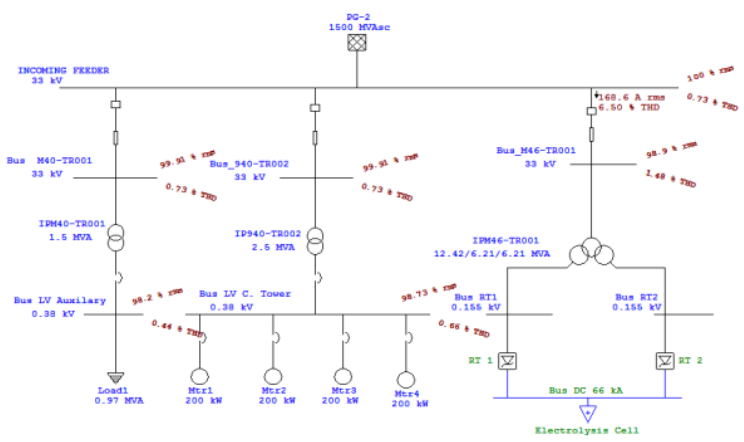

Gambar 10. Simulasi nilai THD arus dan tegangan sebelum pemasangan filter

\section{Simulasi Distorsi Harmonik Arus Sebelum}

\section{Pemasangan Filter}

Berdasarkan hasil dari simulasi sebelum pemasangan filter, maka nilai distorsi harmonik arus pada sisi sumber transformator rectifier IPM46TR001 dapat diamati dalam bentuk gelombang dan spektrum seperti pada Gambar 11 dan 12 berikut :

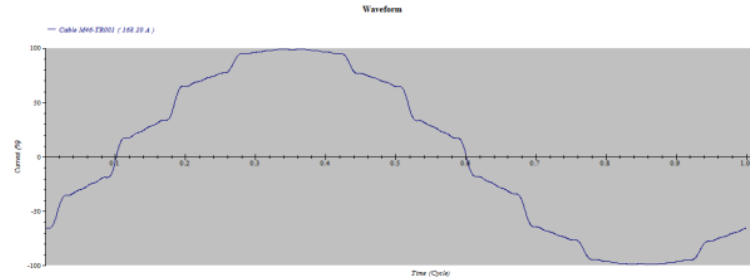

Gambar 11. Gelombang arus akibat adanya distorsi harmonik

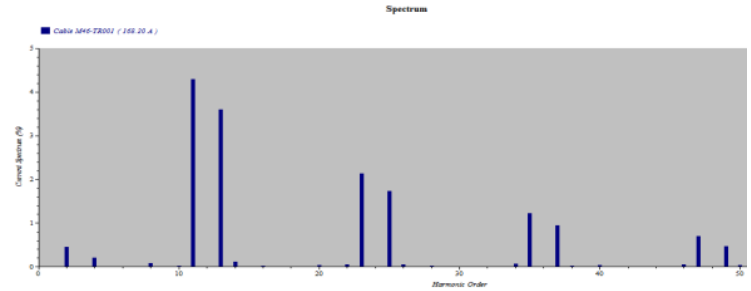

Gambar 12. Spektrum harmonik arus sebelum pemasangan filter

Dari bentuk spektrum arus pada Gambar 12 menunjukkan harmonik arus yang menonjol adalah harmonik pada orde ke-11,13,23 dan 25. Cacatnya bentuk gelombang arus menunjukkan kandungan harmonik yang ditimbulkan cukup besar.

\section{Simulasi Distorsi Harmonik Tegangan Sebelum Pemasangan Filter}

Nilai distorsi harmonik tegangan pada sisi sumber transformator rectifier IPM46-TR001 dapat diamati dalam bentuk gelombang tegangan seperti Gambar 13 dan 14 berikut :

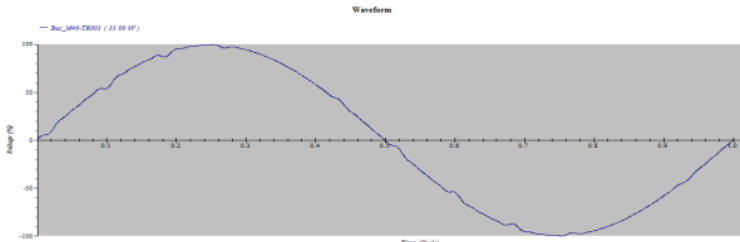

Gambar 13. Gelombang tegangan akibat adanya distorsi harmonik

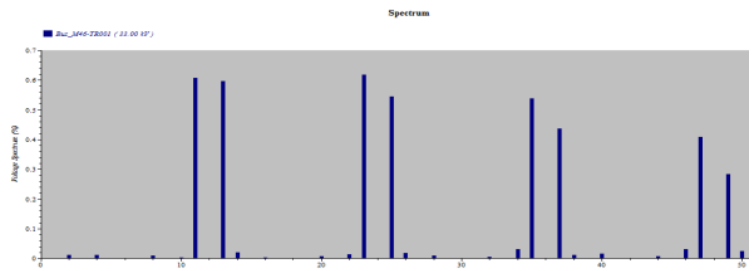

Gambar 14. Spektrum harmonik tegangan sebelum pemasangan filter

Dari bentuk spektrum tegangan pada Gambar 14 
menunjukkan harmonik tegangan yang menonjol adalah harmonik pada orde ke-11,13,23 dan 25, kondisi harmonik yang terjadi pada tegangan merupakan efek dari distorsi harmonik arus yang berasal dari beban nonlinear yang dikirim kesistem.

\section{Analisa Nilai Komponen Filter Pada Simulasi ETAP}

Nilai kapasitor dan induktor merupakan perhitungan substitusi pada simulasi dengan rangkaian filter terhubungan wye $(\mathrm{Y})$ pada tegangan tiga phasa, sedangkan nilai untuk resistor dan nilai tegangan (rate $\mathrm{kV}$ ) menggunakan data hasil perhitungan pada Tabel 9 dan Tabel 10, maka nilai perbandingan untuk masing-masing komponen filter adalah seperti pada Tabel 11 berikut :

Tabel 11. Perbandingan nilai komponen filter hasil simulasi dan perhitungan

\begin{tabular}{cccccc}
\hline $\begin{array}{c}\text { Tega- } \\
\text { ngan } \\
(\mathrm{kV})\end{array}$ & \multicolumn{3}{c}{$\begin{array}{c}\text { Kapasitor }(\mu \mathrm{F}) \\
\text { Satu Phasa }\end{array}$} & \multicolumn{2}{c}{$\begin{array}{c}\text { Reaktansi Induktor } \\
(\Omega) \text { Satu Phasa }\end{array}$} \\
\hline & 11 & 4,173 & 4,867 & 6,543 & 5,404 \\
33 & 13 & 4,173 & 4,898 & 4,657 & 3,845 \\
& 23 & 4,173 & 4,946 & 1,468 & 1,216 \\
& 25 & 4,173 & 4,952 & 1,24 & 1,028 \\
\hline
\end{tabular}

Simulasi Aliran Daya dan THD Sistem Setelah Pemasangan Filter

Berdasarkan hasil simulasi aliran daya pada kondisi pemasangan single tuned filter untuk orde ke-11,13 dan 23 terjadi peningkatan faktor daya (cos $\varphi)$ dari 0,8 menjadi 0,96. Nilai THD arus dan tegangan dari hasil simulasi setelah pemasangan filter seperti pada Gambar 15 berikut :

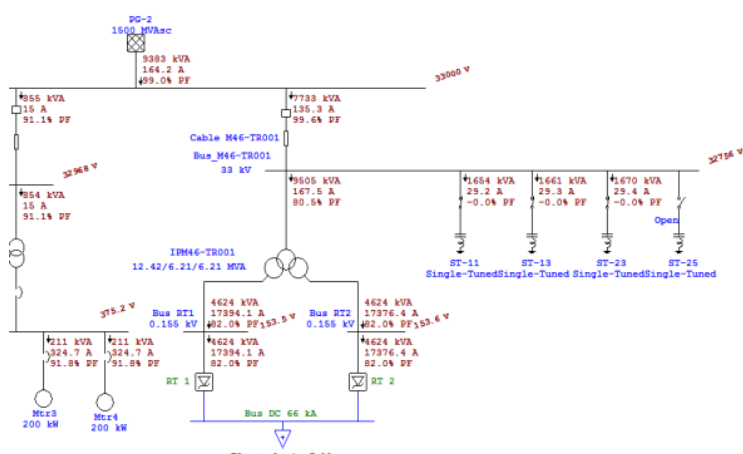

Gambar 15. Simulasi aliran daya sistem setelah pemasangan filter

Dari Hasil simulasi harmonic analysis terjadi penurunan nilai distorsi harmonik arus dari $6,5 \%$ menjadi $0,98 \%$ dan distorsi harmonik tegangan dari $1,48 \%$ menjadi $0,26 \%$. Pemasangan single tuned filter untuk orde ke-11,13 dan 23 sudah cukup efektif untuk memenuhi kebutuhan daya reaktif dan meredam distorsi harmonik pada sistem.

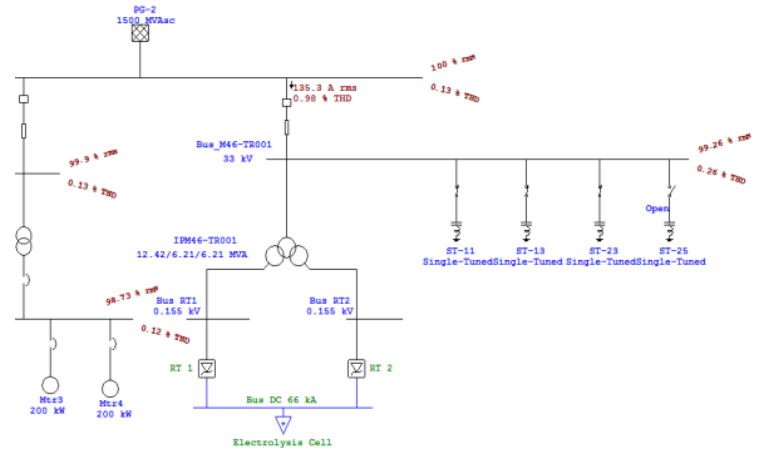

Gambar 16. Simulasi nilai THD arus dan tegangan setelah pemasangan filter

\section{Simulasi Distorsi Harmonik Arus Setelah Pemasangan Filter}

Kondisi dan nilai distorsi harmonik arus pada sisi sumber transformator rectifier IPM46TR001 terjadi penurunan yang dapat diamati dalam bentuk gelombang arus seperti Gambar 17 dan 18 berikut :

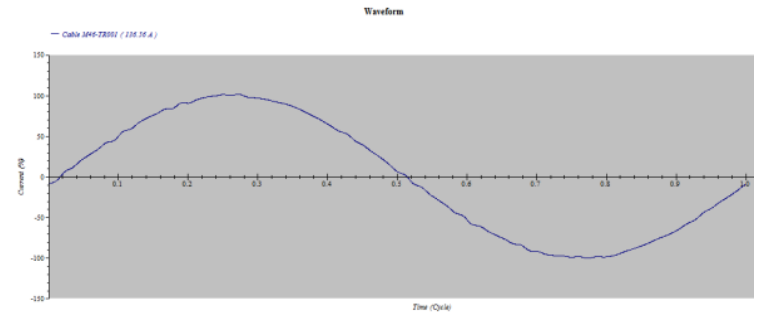

Gambar 17. Gelombang arus setelah pemasangan filter

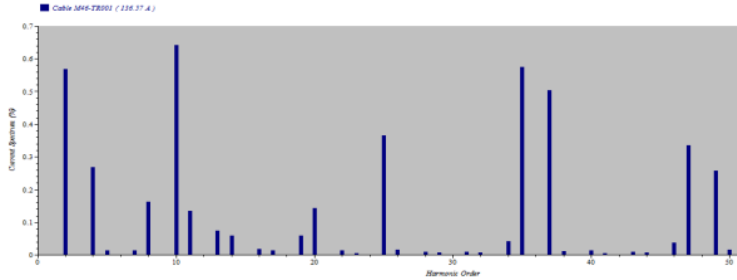

Gambar 18. Spektrum harmonik arus setelah pemasangan filter

\section{Simulasi Distorsi Harmonik Tegangan Setelah Pemasangan Filter}

Kondisi dan nilai distorsi harmonik tegangan terjadi penurunan yang dapat diamati dalam bentuk gelombang dan spektrum tegangan seperti pada Gambar 19 dan 20 berikut :

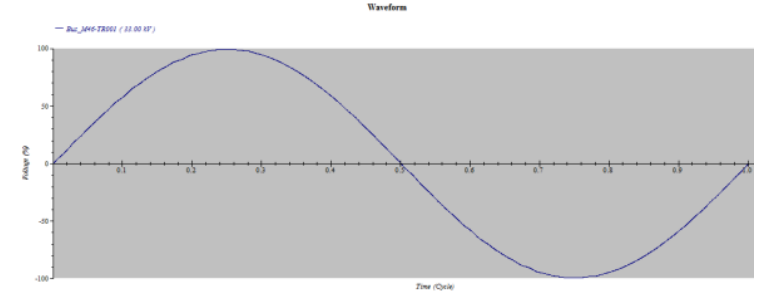

Gambar 19. Gelombang tegangan setelah pemasangan filter 


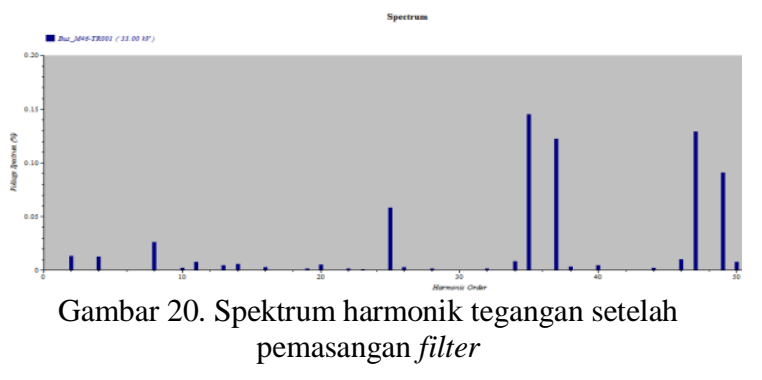

Setelah pemasangan filter, bentuk gelombang arus dan tegangan sudah mendekati kondisi sinusoidal. Perbandingan THD arus dan tegangan serta faktor daya $(\cos \varphi)$ simulasi sebelum dan setelah pemasangan single tuned filter seperti pada Tabel 12 berikut :

Tabel 12. Perbandingan nilai THD arus dan tegangan serta faktor daya hasil simulasi sebelum dan setelah pemasangan filter

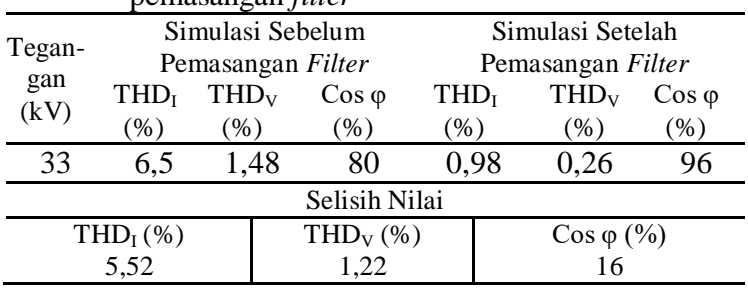

\section{KESIMPULAN}

Berdasarkan hasil perhitungan dan simulasi yang dilakukan, maka dapat dibuat beberapa kesimpulan sebagai berikut :

1. Munculnya harmonik disisi sumber transformator rectifier IPM46-TR001 pada harmonik orde ke-11,13,23 dan 25, maka dapat dilakukan perencanaan pemasangan filter pasif single tuned dengan nilai kapasitor bank filter (C) sama yaitu sebesar 4,173 $\mu \mathrm{F}$. Untuk filter harmonik orde ke-11, nilai induktor (L) adalah sebesar 20,837 $\mathrm{mH}$. Untuk filter harmonik orde ke-13, nilai induktor (L) adalah sebesar 14,833 $\mathrm{mH}$. Untuk filter harmonik orde ke-23, nilai induktor (L) adalah sebesar 4,637 $\mathrm{mH}$, dan untuk filter harmonik orde ke-25, nilai induktor (L) adalah sebesar 3,943 $\mathrm{mH}$.

2. Dari hasil simulasi harmonic analysis menggunakan software ETAP, setelah dilakukan pemasangan filter harmonik orde ke-11,13 dan 23 maka nilai harmonik arus $\left(\mathrm{THD}_{\mathrm{I}}\right)$ dan harmonik tegangan $\left(\mathrm{THD}_{\mathrm{V}}\right)$ terjadi penurunan yaitu sebelum pemasangan filter nilai $\mathrm{THD}_{\mathrm{I}}$ adalah $6,5 \%$, setelah pemasangan filter nilai $\mathrm{THD}_{\mathrm{I}}$ menjadi $0,98 \%$ terjadi penurunan $\mathrm{THD}_{\mathrm{I}}$ sebesar $5,52 \%$ dan distorsi harmonik tegangan dari $1,48 \%$ menjadi $0,26 \%$, terjadi penurunan $\mathrm{THD}_{\mathrm{V}}$ sebesar $1,22 \%$. Pemasangan tiga unit filter harmonik yaitu orde ke-11,13 dan 23 sudah efektif untuk meredam distorsi harmonik pada sistem.

3. Dari hasil simulasi aliran daya (load flow analysis) menggunakan software ETAP, setelah dilakukan pemasangan filter terjadi peningkatan nilai faktor daya $(\cos \varphi)$ yaitu sebelum pemasangan filter nilai faktor daya $(\cos \varphi)$ adalah 0,8 , setelah pemasangan filter nilai faktor daya $(\cos \varphi)$ menjadi 0,96 , terjadi peningkatan faktor daya sebesar $16 \%$.

\section{DAFTAR PUSTAKA}

[1] S.V.Kulkarni and S.A.kharparde, Transformer Engineering: Design and Practice. New York: Marcel Dekker.Inc, 2004.

[2] S. Crepaz, "For an Improved Evaluation of Conventional Losses Transformers for Converters," IEEE Trans. Ind. Appl., 1975.

[3] IEEE Standard 519-1992, IEEE Recommended Practices and Requirements for Harmonic Control in Electrical Power Systems. New York: IEEE Inc, 1992.

[4] R. c. Dugan, M. F. McGranahgan, S. Santoso, and H. W. Beaty, Electrical Power Systems Quality, Second Edi. New York: McGraw-Hill, 2004.

[5] F. C. D. La Rosa, Harmonics And Power Systems. Hazelwood, Missouri, U.S.A: Taylor \& Francis Group, 2006. 